\title{
SOSIALISASI DAN PELATIHAN PEMBUATAN MINUMAN FUNGSIONAL REMPAH (MUFIRA) READY TO DRINK DI KELURAHAN TANJUNG KRAMAT KOTA GORONTALO
}

\section{Socialization and training of making functional drinking (mufira) ready to drink in Tanjung Kramat, Gorontalo City}

Syahmidarni Al Islamiyah" ${ }^{1)}$, Rosdiani Azis ${ }^{2)}$, Satria Wati Pade ${ }^{3)}$

${ }^{1,2,3)}$ Dosen Program Studi Teknologi Hasil Pertanian, Politeknik Gorontalo E-mail : islamiyah01@poligon.ac.id ${ }^{1)}$

\begin{abstract}
ABSTRAK
Dunia sedang digemparkan dengan merebaknya wabah virus corona yang mematikan. Provinsi Gorontalo merupakan salah satu daerah yang terjangkiti virus ini. Pemerintah Provinsi Gorontalo memberlakukan protokol pencegahan sesuai anjuran WHO. Salah satunya dengan mengkonsumsi makanan/minuman yang membantu meningkatkan daya tahan tubuh seperti rempah-rempah. Oleh karena itu, tim pengabdian Politeknik Gorontalo melakukan kegiatan sosialisasi dan pelatihan kepada masyarakat tentang pembuatan produk minuman fungsional siap minum (ready to drink) berbahan dasar rempah. Tujuannya untuk memberi pengetahuan dan skill kepada masyarakat sehingga dapat diaplikasikan di rumah. Pengabdian ini dilakukan di Kelurahan Tanjung Kramat. Metode pelaksanaan dilakukan secara daring dengan menggunakan aplikasi zoom. Hasil dari kegiatan pengabdian ini antara lain tercapainya kerjasama yang sinergis antara pemerintah, akademisi dan masyarakat dalam meningkatkan immunitas guna mencegah penyebaran virus covid-19, masyarakat mengetahui dan memiliki keterampilan mengolah rempah menjadi minuman fungsional sehingga terwujud masyarakat yang sehat dan daya tahan tubuh yang baik dan meningkatnya peran serta masyarakat dan akademisi dalam membantu upaya pemerintah mencegah penyebaran virus covid-19 di Provinsi Gorontalo.
\end{abstract}

Kata kunci: sosialisasi; pelatihan; minuman fungsional; rempah; ready to drink

\begin{abstract}
The world is in shock with the outbreak of a deadly coronavirus. Gorontalo Province is one of the areas affected by this virus. The Gorontalo provincial government has implemented a preventive protocol as recommended by WHO. One of the prevention efforts is consuming foods/drinks that help increase endurance, such as spices. Therefore, the Gorontalo Polytechnic service team conduct socialization and training activities to the community how process of ready to drink functional beverage products made from spices. The goal was to provide knowledge and skills to the community so that they can be applied at home. This service was carried out in Tanjung Kramat Village. The method of implementation is carried out online by using a zoom application. The results of this service activities include the achievement of synergic cooperation between the government, academics, and the community in increasing immunity to prevent the spread of the Covid-19 virus, the public knows and has the skills to process spices into functional drinks so that a healthy community and good immune system can be realized. increasing the participation of the community and academics in helping the government's efforts to prevent the spread of the COVID-19 virus in Gorontalo Province.
\end{abstract}

Keywords: socialization; training; functional drinks; spices; ready to drink 


\section{PENDAHULUAN}

Dunia saat ini digemparkan dengan merebaknya wabah virus corona $(\mathrm{CoV})$ yang mematikan. Menurut peneliti, virus covid-19 ini merupakan virus corona jenis baru yang hidup dengan menginfeksi hewan dan dapat berevolusi dan menyebar ke manusia. Pandemi covid-19 ini telah memakan banyak korban jiwa. Negara kita Indonesia semakin hari pertambahan positif corona semakin meningkat. Adapun berdasarkan Pusat Krisis Kemenkes jumlah pengidap yang positif di Indonesia per 19 April 2020 adalah sekitar 6.057 orang dan jumlah kematian sekitar 582 orang. Hampir seluruh negara di dunia mengalami kasus akibat virus mematikan ini seperti China, negara Eropa, Amerika bahkan ke negara Asia termasuk Indonesia.

Provinsi Gorontalo merupakan salah satu daerah di Indonesia yang terjangkiti virus ini dengan kasus pertama kali menurut Dinas Kesehatan Provinsi Gorontalo (2020) terjadi awal April ini. Data pasien positif covid per april adalah 4 orang (Kabupaten Pahuwato 1 orang, Kota Gorontalo 2 orang dan Kabupaten Bone Bolango 1 orang), status ODP sekitar 588 orang, dan status PDP sebanyak 33 orang. Oleh karena itu, pemerintah Provinsi Gorontalo segera memperketat langkah pencegahan penyebaran agar tidak semakin meluas dengan memberlakukan Sosial Distanching, Work From Home, bagi masyarakat yang beraktivitas di luar rumah diwajibkan menaati protokol kesehatan sebagaimana yang dianjurkan WHO seperti cuci tangan sesering mungkin, penggunaan masker, jaga jarak, mengkonsumsi makanan dan minuman sehat yang membantu meningkatkan daya tahan tubuh dan pembatasan waktu aktivitas baik perkantoran, perbelanjaan, dan arus kendaraan.

Menurut para ahli virus, virus corona termasuk virus yang menyerang/menginfeksi sistem pernapasan.
Pada banyak kasus, gejala awal serangan virus ini berupa infeksi pernapasan ringan, seperti flu. Menurut penelitian dan para ahli menjelaskan bahwa gejala dari Covid-19 ini muncul dalam waktu 2 hari sampai 2 minggu setelah terpapar/terinfeksi. Sistem imun tubuh kita mengenali ada benda asing dalam waktu 7 hari, dan 7 hari setelahnya tubuh akan membuat antibodinya selama tubuh kita dalam keadaan sehat (Anonim c, 2020).

Upaya pencegahan virus ini menurut Kementerian Kesehatan salah satunya adalah dengan menjaga pola makan dengan mengkonsumsi makanan bergizi dan meminum minuman sehat yang berasal dari rempah-rempah. Berdasarkan hasil penelitian yang telah dilakukan oleh guru besar biologi molekuler dari Universitas Airlangga (Unair), Chaerul Anwar Nidom, menyampaikan hasil penelitiannya yaitu minum jamu tertentu dapat menambah daya tahan tubuh sehingga tidak mudah terserang virus. Pendapat beliau bahwa penularan infeksi virus corona bisa dicegah menggunakan rempah seperti temulawak, jahe, dan kunyit. Kurkumin yang terkandung pada jahe, kunyit, temulawak bisa menghambat badai sitokin (Anonim $b$, 2020).

Pendapat tersebut diperkuat oleh penjelasan dari Dekan Sekolah Farmasi Institut Teknologi Bandung (ITB) Prof Daryono Hadi Tjahjono yang mengatakan bahwa tanaman herbal seperti kunyit dan temulawak bermanfaat sebagai salah satu cara untuk membantu pencegahan penyebaran Covid-19. Dari laman resmi ITB, Daryono menjelaskan bahwa kunyit atau Curcuma longa $L$ memiliki kandungan senyawa metabolit bahan alam berupa kurkumin yang memiliki potensi terapeutik yang beragam seperti antibiotik, antiviral, antioksidan, antikanker, dan untuk penanganan penyakit alzheimer. Kurkumin atau turunannya kurkuminoid juga terdapat pada temulawak, jahe, dan 
tanaman sejenis. Selain senyawa tersebut juga terdapat puluhan senyawa kimia lain secara empiris gabungan kandungan senyawa kimia dari tanaman tersebut yang bermanfaat sebagai imunomodulator yang menjaga daya tahan tubuh. Efek pengobatan dari gabungan senyawa kimia (multi compound) pada tanaman tersebut berbeda dengan efek farmakologi senyawa kurkumin secara tunggal (single compound). Dalam kaitannya dengan Covid-19, pemanfaatan tanaman tersebut baik secara tunggal maupun gabungannya dapat membantu meningkatkan daya tahan tubuh sebagai imunomodulator. Oleh karena itu, pemanfaatan kunyit, temulawak atau jahe sebagai jamu, obat herbal terstandarkan, atau suplemen minuman adalah aman (Anonim b, 2020).

Kunyit, jahe, temulawak, dan rempah lainnya adalah tanaman yang umumnya tumbuh liar sehingga mudah diperoleh. Masyarakat Indonesia memiliki kebiasaan menggunakan tanaman tersebut untuk dijadikan sebagai rempah atau bumbu masakan dan jamu. Selain tanaman tersebut, sereh dan kayu manis juga termasuk rempah yang memiliki citarasa dan efek aroma yang kuat serta kaya kandungan antioksidan menjadikan rempah ini sangat bermanfaat untuk kesehatan terutama memperkuat daya tahan tubuh. Antioksidan juga berfungsi dalam melindungi dan memperbaiki sel tubuh dari kerusakan akibat radikal bebas (Anonim a, 2020).

Kota Gorontalo memiliki potensi alam yang melimpah karena letaknya di pinggiran pantai, salah satunya adalah kelurahan Tanjung Kramat. Kelurahan ini letaknya sekitar 30 menit dari Kota gorontalo. Kelurahan Tanjung Kramat merupakan salah satu Kelurahan di Kabupaten Gorontalo yang memiliki sumber daya yang bisa dimanfaatkan untuk dijadikan minuman fungsional rempah tetapi pengetahuan tentang tindakan pencegahan penularan covid-19 dengan produk pangan/rempah masih kurang. Dengan demikian, perlu dilakukan suatu upaya pihak akademisi yang bersinergi dengan pemerintah untuk memberikan pengetahuan dan keterampilan guna mencegah penularan virus covid-19 melalui peningkatan daya tahan tubuh (immunitas). Selain itu, aparat di kelurahan ini sudah terbiasa melakukan komunikasi melalui teknologi dengan zoom. Oleh karena itu, tim pengabdian Poligon berinisiatif untuk melakukan sosialisasi dan pelatihan pembuatan minuman berbahan dasar rempah siap minum (ready to drink) kepada masyarakat setempat.

Tujuannya agar masyarakat dapat mengaplikasikan pembuatan minuman fungsional ini di rumah. Dengan demikian, akan memicu peningkatan imuninitas masyarakat di kelurahan tersebut sehingga dapat mencegah terjangkitnya virus Covid 19.

\section{METODE PELAKSANAAN KEGIATAN}

Pengabdian Kepada Masyarakat (PKM) ini dilaksanakan pada bulan April tahun 2020 di Kelurahan Tanjung Kramat Kota Gorontalo pada pukul 10.00 WITA sampai selesai melalui aplikasi zoom. Pelaksanaan kegiatan pengabdian dilakukan dalam beberapa tahap yakni :

1) Identifikasi masalah dan cara pemecahannya. Tujuannya untuk mengetahui masalah yang dihadapi oleh masyarakat dalam upaya pencegahan penyebaran virus covid-19 sehingga dengan demikian dapat diketahui solusi pemecahan masalah tersebut.

2) Koordinasi dengan pihak setempat Rencana kegiatan ini dikoordinasikan kepada semua pihak yang akan dilibatkan terutama pihak pemerintah dan masyarakat Kelurahan Tanjung Kramat. Hal ini agar pelaksanaan kegiatan dapat berjalan sesuai tujuan dan harapan terutama dalam membantu masyarakat 
dalam mencegah penyebaran infeksi virus covid-19 ini.

3) Persiapan tim dan teknis pelaksanaan kegiatan.

Tahap persiapan ini dilakukan untuk mempersiapkan kebutuhan utama maupun kebutuhan pendukung kegiatan. Kebutuhan utama seperti materi sosialiasi serta alat bahan pengolahan minuman fungsional. Sedangkan kebutuhan pendukung seperti perangkat audio visual, absen peserta, konsumsi, dll. Teknis pelaksanaan kegiatan terdiri dari sosialisasi/penyuluhan, praktek dan diskusi interaktif.

4) Pelaksanaan kegiatan sosialisasi edukasi dan praktek pembuatan minuman fungsional rempah, dimulai dengan penjelasan teori tentang rempah dan pembuatan minuman fungsional dengan menggunakan media penyampaian dalam bentuk powerpoint, praktek pembuatan minuman fungsional yang ditunjukkan kepada peserta melalui media online via zoom. Untuk memudahkan duplikasi resep maka tim pengabdian akan membagikan booklet resep minuman fungsional ini dalam bentuk softfile ataupun hardfile bersamaan dengan pembagian produk.

5) Diskusi interaktif, dilakukan untuk menjalin komunikasi interaktif dengan peserta dan memberi kesempatan untuk berbagi ilmu dan pengalaman terutama terkait dengan pencegahan penyebaran virus covid-19 ini.

6) Evaluasi dan pembagian produk minuman fungsional.

Tahap ini dilakukan untuk melihat sejauh mana tujuan tercapai dan manfaat dapat dirasakan oleh semua pihak yang terlibat terkhusus masyarakat Kelurahan Tanjung Kramat sebagai target utama, serta melihat kekurangan selama proses pengabdian sehingga menjadi perbaikan ke depan. Selain itu, kegiatan ini diakhiri dengan pembagian produk minuman fungsional kepada masyarakat sebagai wujud nyata peran serta dan bentuk kepedulian Kampus Politeknik Gorontalo dalam membantu pemerintah Gorontalo dalam mencegah penyebaran virus Covid-19 ini.

\section{HASIL DAN PEMBAHASAN}

Hasil dari kegiatan ini dapat dilihat dari proses dan respon dari masyarakat selama dan setelah kegiatan. Setelah seluruh rangkaian kegiatan PKM ini dilaksanakan, masyarakat Tanjung Kramat akhirnya memiliki pengetahuan tentang bahaya virus covid-19 dan cara pencegahannya. Pengetahuan masyarakat tentang rempahrempah yang biasanya dan umumnya hanya digunakan di dapur sebagai bumbu masakan, mereka akhirnya memahami bahwa rempah ini juga bisa dimanfaatkan sebagai bahan dasar pengolahan minuman fungsional yang bisa meningkatkan daya tahan tubuh dan membantu mempertahankan tubuh dari infeksi virus. Selain pengetahuan, masyarakat Tanjung Kramat juga keterampilan dalam menginovasikan produk lokal menjadi meningkat.

Keterampilan yang diberikan berupa cara mengolah rempah-rempah menjadi minuman fungsional ready to drink yang siap dikonsumsi kapan pun, dimana pun dan tahan lama, cara mengolah yang baik dan tepat sehingga gizi dari rempah tidak hilang saat pengolahan serta cara menyimpan agar bertahan lama. Dengan demikian, setelah masyarakat mengikuti kegiatan ini, mereka tidak hanya mengetahui teknik penangangan, pengolahan tetapi teknik mempertahankan mutu dan gizi dari minuman fungsional rempah tersebut.

Hasil kegiatan pengabdian via daring ini berjalan lacar dan sangat memuaskan. Hal ini terlihat dari sikap penerimaan pihak pemerintah Kelurahan Tanjung Kramat yang sangat terbuka dari awal sampai akhir, antusiasme peserta selama kegiatan, 
menyimak semua materi yang disampaikan dan interaktif. Proses penyampaian materi juga berjalan lancar meski di awal terganggu oleh jaringan karena kegiatan dilakukan secara online (daring).

Selama proses kegiatan berjalan, tim pengabdian tetap menjalankan protokol kesehatan seperti memakai masker, jaga jarak, menggunakan handsanitizer/cuci tangan sebelum/sesudah melakukan kegiatan.

Kekurangan yang dirasakan oleh tim selama pengabdian adalah jaringan yang kurang stabil, sehingga terkadang terhenti/terputus. Keterbatasan ruang dan waktu, penyampaian melalui aplikasi zoom yang hanya mengandalkan jaringan internet sehingga seringkali mengalami kendala teknis seperti suara yang kurang terdengar jelas serta gambar yang tidak terlalu terang pada saat penyampaian informasi. Oleh sebab itu, tim pengabdi telah menyediakan bahan bahan serta minuman fungsional yang sudah diolah beberapa hari sebelum pelaksanaan pelatihan untuk menyiasati jika terjadi putusnya saluran koneksi internet. Agar mitra lebih paham, tim pengabdi memberikan simulasi pembuatan minuman fungsional rempah dalam bentuk video yang ditampilkan pada saat kegiatan berlangsung.

Kegiatan ini ditutup dengan pembagian produk minuman fungsional rempah ini kepada masyarakat Tanjung Kramat yang penyerahannya diwakilkan kepada pihak pemerintah dalam hal ini lurah Tanjung Kramat. Berikut gambar kegiatan pengabdian oleh tim :

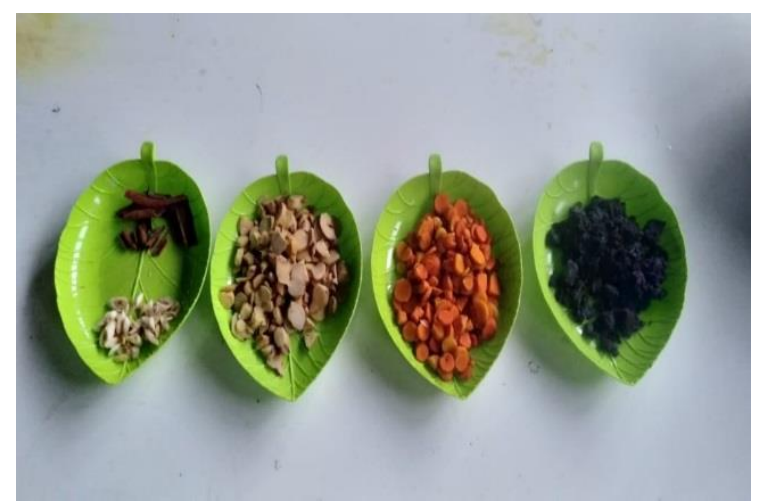

Gambar 1. Bahan-bahan

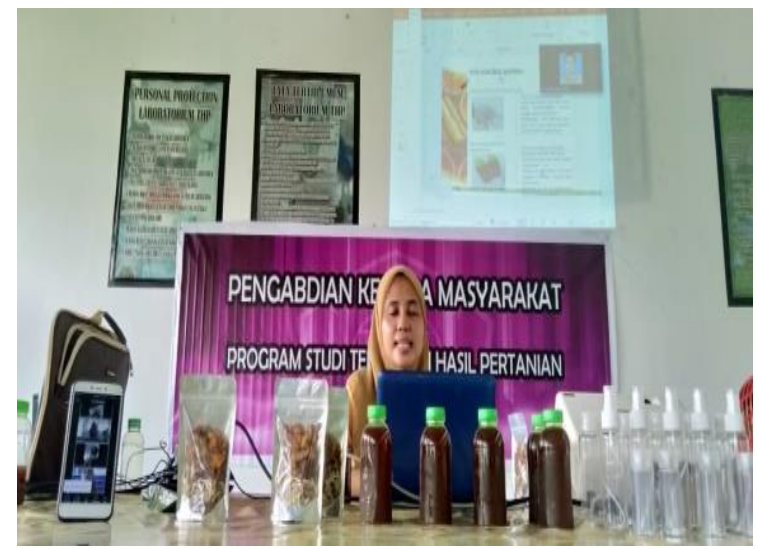

Gambar 2. Proses Pemaparan materi sosialisasi dan pengolahan produk mufira ready to drink secara daring

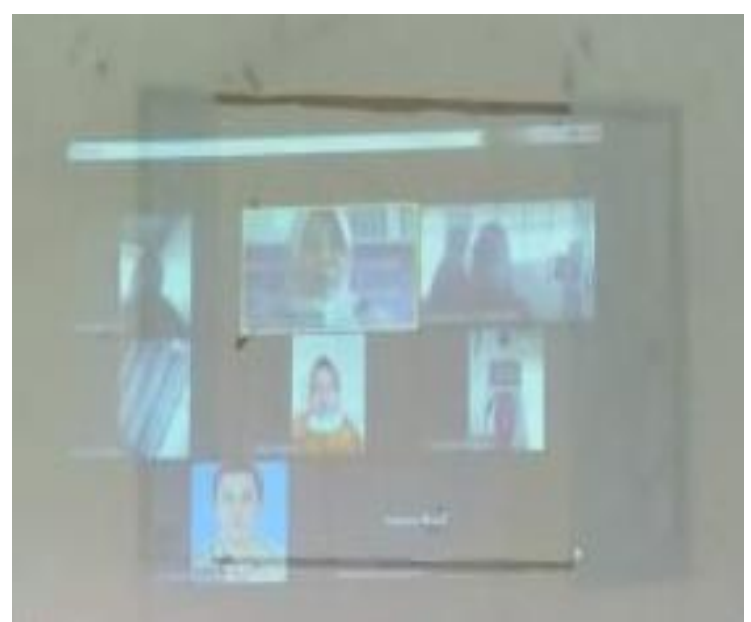

Gambar 3. Tampilan peserta pengabdian daring via zoom 


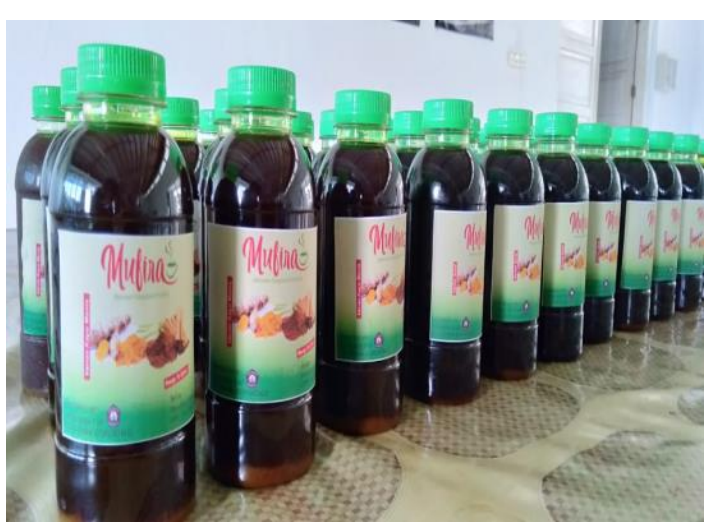

Gambar 4. Produk mufira ready to drink



Gambar 5. Tim Pengabdian



Gambar 5. Penyerahan produk mufira kepada lurah Tanjung Kramat

\section{KESIMPULAN}

Kesimpulan pada kegiatan pengabdian ini antara lain tercapainya kerjasama yang sinergis antara pemerintah, akademisi, dan masyarakat dalam meningkatkan immunitas guna mencegah penyebaran virus covid-19. Memperbarui dan meningkatkan pengetahuan dan keterampilan mengolah potensi lokal terutama rempah menjadi minuman fungsional sehingga terwujud masyarakat yang sehat dan daya tahan tubuh yang baik sehingga terlindungi dari infeksi virus covid-19. Peningkatan peran serta masyarakat dan akademisi dalam membantu upaya pemerintah mencegah penyebaran virus covid-19 di Kelurahan Tanjung Kramat khususnya dan di Provinsi Gorontalo umumnya.

\section{DAFTAR PUSTAKA}

Anonim a, 2020. Penjelasan ahli farmakologi soal keampuhan kunyit dan temulawak mencegah corona covid-19.

https://www.liputan6.com/regional/r ead/4207472/penjelasan-ahlifarmakologi-soal-keampuhankunyit-dan-temulawak-cegahcorona-covid-19. Akses : 20 April 2020 .

Anonim b, 2020. Cara mencegah virus corona menurut para ahli. https://www.industry.co.id/read/616 31/catat-ini-cara-mencegah-viruscorona-menurut-para-ahlikesehatan. Akses : 20 April 2020.

Anonim c, 2020. Ahli virologi virus corona jenis bary $80 \%$ mirip SARS. https://kumparan.com/kumparansain s/ahli-virologi-virus-corona-jenisbaru-80-persen-mirip-sars1smPjfzvH9A. Akses : 20 April 2020.

Dinas Kesehatan Provinsi Gorontalo, 2020. Data Perkembangan Pandemik Covid-19 di Provinsi Gorontalo. 
www.dinkes.gorontaloprov.go.id/co vid-19. Akses : 20 April 2020.

Pusat Krisis Kesehatan Kemenkes 2020, Perkembangan Kasus Komulatif per $19 \quad$ April 2020. www.pusatkrisis.kemenkes.go.id.

Akses : 20 April 